The question of what degree of evidence a single bloody smudge may give of the identity of some supposed miscreant with a convict having a previous official record is a matter for dispute. Still more is that of a case where, say, the right forefinger of Richard Roe may be practically identical with the left ring-finger of John Doe. Such similarity would be no evidence whatever for personal identification. In labouring to be brief I trust I have not been quite obscure. Sir William, in his review of the history of this discovery, has not made any reference to my little contributions on the subject. He, however, did acknowledge my priority of publication in your columns of November 22, 1894, and for that "gift granted" I must feel grateful.

Stoke-on-Trent.

I HAVE to thank you for your courtesy in forwarding me a copy of Mr. Faulds's letter to you, and, in compliance with your request, I submit the following remarliss.

The only point I feel bound to notice is his complaint that I have not mentioned his name in my story of "The Origin of Finger-Printing." Mr. Faulds's own account of his claim has been so fully placed before the public in his letters to you from Japan, of October, I88o, and later, that $I$ think I was right in keeping to that period of history, twenty years further back than his, which lay within my own know ledge.

But his present letter breaks through all bounds of social courtesy, and it is only his position as a professed man of science that justifies me in correcting him. Mr. Faulds has the temerity to scout my statement that I was moved to study finger-printing by the fascination of Kōnāi's hand-mark (taken as it was for the same purpose as finger-prints now are). The finger-tips were badly smudged; but the small furrows on the palm were exquisite, and moved me to take better impressions than his from my own fingers, as I tell the reader on the same page, only $\mathrm{Mr}$. Faulds ignores it. This is not the spirit of science.

I will now, with your permission, show reason why I could not honestly have introduced Mr. Faulds's name. His letter of 1880 announced that in the previous year his attention was directed to the peculiarities of finger impressions on pottery, and that he had come to the conclusion, by original and patient experiment, that finger-prints were sufficiently personal in pattern to supply a long-wanted method of scientific identification, which should enable us to fix his crime upon any offender who left finger-marks behind him, and equally well to disprove the suspected identity of an innocent person. (For all which I gave him, and I still do so, the credit due for a conception so different from mine.) But he went on to say :- "There can be no doubt of the advantage of having a copy of the for-ever-unchangeable finger-furrows of important criminals."

This expression made me protest at once, in my reply, that I could not understand how, in less than two years, he could have come to the knowledge that the furrows were unchangeable. It had taken me nearly twenty years of sustained experiment to demonstrate this persistence of the patterns for at least fifteen years of a man's life, and it is plainly impossible for any man with a scientific turn of mind to put this doctrine forward after only twenty months or so of experiment. My reply, therefore, of 1880 expressly challenged his authority for the statement, and he has never justified it. My challenge did oblige him to meet it as best be could, but the nearest approach I have seen to an answer is the following extract from an article of his in Knowledge, April, rgr I :--

NO. 2464 , VOL. 987
"The mode I took to test whether the ridges ever shifted their situation or changed their form was by shaving away their elevations ... having first taken careful imprints of the patterns. After the skin grew up again. fresh imprints were taken and compared with the old ones, . . . but in many hundreds of cases, ested thus three or four times, not one solitary example of a variation in pattern was detected." His return to England broke the further investigation. He goes on to say :- "The firm conviction, however, was established in my mind, which nothing has occurred to change, that skin furrows for the purposes of identification are invariable throughout life."

This quotation is his latest statement of his authority, but it needs to be read with an extract from a previous letter of his, dated June 5 , 1909, in which he says :-

"One of my earliest experiments was to shave off the ridges of the finger-tips with razors; the pattern on the skin was reproduced with quite unvarying fidelity, unless part of the true (deep) skin was removed."

I take it that this is the only foundation he has for his claim to have known the law of persistency in I880. I leave it to men of science to judge whether his experiments sufficed to prove persistency of a finger pattern for life.

Warfield.

\section{The Date of the Introduction of the Term "Metabolic."}

THE concept and the term "metabolism" have played such a prominent part in the development of physiological science that it should be interesting to know by whom, and when, the term was first used. Prof. Bayliss, in his "Principles of General Physiology" (19I5, p. 263), says that, so far as he can discover, "metabolism" was first used by Sir Michael Foster in his "Text-book of Physiology," the first edition of which was published in 1883 . It seems, however, that there is a still earlier use of the term in the writings of no less well known an investigator than Theodore Schwann, enunciator of the cell-theory. The passage $I$ allude to occurs in the chapter called "Theory of Cells," the last in Section III. of Schwann's classic, "Microscopical Researches into the Accordance in the Structure and Growth of Animals and Plants, by Dr. Th. Schwann, Professor in the University of Louvain," published in Berlin in 1839. My translation of it is that made in 1847 by Dr. Henry Smith, of London, for the Sydenham Society; it runs thus (p. I93):"The question, then, as to the fundamental power of organised bodies resolves itself into that of the fundamental powers of the individual cells.... These phenomena may be arranged in two natural groups: first, those which relate to the combination of molecules to form a cell; secondly, those which result from chemical changes either in the component particles of the cell itself or in the surrounding cytoblastema, and may be called metabolic phenomena ( тò $\mu \epsilon \tau a \beta o \lambda \iota k \dot{\nu}$, implying that which is liable to occasion or suffer change)." The italics are in the oniginal. Here, then, so far as I know, is the first use of the term "metabolic," though undoubtedly not the first accurrence of the conception of chemical changes in living matter. Schwann uses the term "metabolic" exactly in its present-day sense, the phenomena of change, interchanges, of material in and by living matter.

The year 1839 may be taken as the date of the introduction into biological terminology of the expression "metabolic," and the person Theodore Schwann, at one time professor in the ancient University of Louvain. 